\title{
Nutritional and lipid profiles of the dorsal and ventral muscles of wild pirarucu
}

\author{
Carlos Andre Amaringo Cortegano(1), Leandro Cesar de Godoy(2), Maria Eugênia Petenuci(3), \\ Jesuí Vergílio Visentainer ${ }^{(3)}$, Elizabeth Gusmão Affonso ${ }^{(1,4)}$ and Ligia Uribe Gonçalves ${ }^{(1,4)}$
}

\begin{abstract}
(1)Universidade Nilton Lins, Programa de Pós-Graduação em Aquicultura, Avenida Professor Nilton Lins, no 3259, Parque das Laranjeiras, CEP 69058-030 Manaus, AM, Brazil. E-mail: carlosand8@hotmail.com (2)Universidade Federal do Rio Grande do Sul, Departamento de Zootecnia, Avenida Bento Gonçalves, no 7.712, CEP 91540-000 Porto Alegre, RS, Brazil. E-mail: leandro.godoy@ufrgs.br (3)Universidade Estadual de Maringá, Departamento de Química, Avenida Colombo, № 5.790, CEP 87020-900 Maringá, PR, Brazil. E-mail: petenuci@ibest.com.br, jvvisentainer@uem.br ${ }^{(4)}$ Instituto Nacional de Pesquisas da Amazônia, Avenida André Araújo, no 2.936, CEP 69060-001 Manaus, AM, Brazil. E-mail: pgusmao@inpa.gov.br, ligia.goncalves@inpa.gov.br
\end{abstract}

\begin{abstract}
The objective of this work was to analyze the proximate and fatty acid composition of the dorsal and ventral muscles of wild pirarucu (Arapaima gigas) captured from a Brazilian Amazonian lake. Dorsal and ventral muscles were dissected out, freeze-dried, vacuum-packed, and had the proximate and fatty acid composition analyzed. Ash, total proteins, and lipids were inversely proportional to moisture and had higher levels in the ventral muscles. Twenty-seven fatty acids were quantified in both muscles without significant differences between them, except for the heneicosylic, palmitoleic, $\gamma$-linolenic, and dihomo- $\gamma$-linolenic acids. Saturated and monounsaturated fatty acids were predominant in both muscles. The eicosapentaenoic (EPA) and docosahexaenoic (DHA) acids were quantitatively similar: 9.25 (dorsal) to 10.14 (ventral) and 8.50 (dorsal) to 10.63 (ventral) $\mathrm{mg} \mathrm{g}^{-1}$ of total lipids, respectively. The EPA+DHA content of the dorsal and ventral muscles were 113.25 and $165.78 \mathrm{mg} 100 \mathrm{~g} \mathrm{~g}^{-1}$, respectively. The ratios of polyunsaturated/saturated $(0.54$ and 0.59 for the dorsal and ventral muscles, respectively), n-3/n-6 (0.20 and 0.21), and hypocholesterolemic/ hypercholesterolemic fatty acids (1.41 and 1.45) ratios, as well as the atherogenicity $(0.59$ and 0.53$)$ and thrombogenicity (1.02 and 0.94$)$ indices, indicate that pirarucu muscle is a good dietary source of EPA+DHA, and its nutritional lipid quality can be beneficial for human health.
\end{abstract}

Index terms: Arapaima gigas, fatty acids, flesh lipid quality, n-3 Hufa, n-3/n-6, nutraceutical fish.

\section{Perfis nutricionais e lipídicos dos músculos dorsal e ventral em pirarucus selvagens}

Resumo - O objetivo deste trabalho foi avaliar a composição proximal e de ácidos graxos dos músculos dorsal e ventral em pirarucus (Arapaima gigas) selvagens, capturados em um lago amazônico brasileiro. Os músculos dorsal e ventral foram dissecados, liofilizados, embalados a vácuo, e sua composição proximal e de ácidos graxos foram analisadas. Cinzas, proteínas totais e lipídeos foram inversamente proporcionais à umidade e apresentaram teores maiores no músculo ventral. Foram quantificados 27 ácidos graxos em ambos os músculos sem diferença significativa entre eles, exceto para os ácidos heneicosílico, palmitoleico, $\gamma$-linolênico e dihomo$\gamma$-linolênico. Ácidos graxos saturados e monoinsaturados predominaram em ambos os músculos. $\mathrm{O}$ ácido eicosapentaenoico (EPA) e o docosahexaenoico (DHA) foram quantitativamente similares 9,25 (dorsal) a 10,14 (ventral) e 8,50 (dorsal) a 10,63 (ventral) $\mathrm{mg} \mathrm{g}^{-1}$ do total de lipídeos, respectivamente. O conteúdo de EPA+DHA nos músculos dorsal e ventral foi 113,25 e $165,78 \mathrm{mg} 100 \mathrm{~g}^{-1}$, respectivamente. A proporção de ácidos graxos poli-insaturados/saturados (0,54 e 0,59 para os músculos dorsal e ventral, respectivamente), n-3/n-6 (0,20 e 0,21) e hipocolesterolêmicos/hipercolesterolêmicos $(1,41$ e 1,45), assim como os índices de aterogenicidade $(0,59 \mathrm{e}$ $0,53)$ e trombogenicidade $(1,02$ e 0,94$)$, indicam que o músculo do pirarucu pode ser considerado uma boa fonte dietética de EPA+DHA, e a qualidade nutricional de seus lipídios pode ser benéfica para a saúde humana.

Termos para indexação: Arapaima gigas, ácidos graxos, qualidade lipídica da carne, Hufa n-3, n-3/n-6, peixe nutracêutico.

\section{Introduction}

Pirarucu (Arapaima gigas) (Schinz, 1822) is the world's largest scaled freshwater fish, which is native to the Amazon basin and belongs to the most basal branch of extant Teleostei. This is a carnivorous fish reaching sizes of $3 \mathrm{~m}$ in length and weighting up to 200 
kilograms (Fontenele, 1948). Arapaima gigas has an obligatory air-breathing system, moving to the water surface to breathe every 5 to 15 minutes (Fontenele, 1948), which makes it easy its identification and capture by fishermen. It is an emblematic species of the Amazonian ichthyofauna that has become very uncommon in the wild due to the overfishing in the last decades (Cavole et al., 2015), except in some natural reserves such as Pacaya-Samiria, in Peru, and Mamiraua, in Brazil (Núñez et al., 2011). Nowadays, A. gigas is in the Appendix II of the Convention on International Trade of Endangered Species of Wild Fauna and Flora, which means that its trade is controlled as a strategy to preserve the fish stocks (Cites, 2015). In Brazil, its fishing is regulated and only allowed under a community-based sustainable management system in protected areas during the dry season (Cavole et al., 2015).

Due to its large size, A. gigas represents a potential food resource not only for national trade in Amazonian regions, but also for international trade. In fact, this species has already been introduced in the United States (Hill \& Lawson, 2015; Lawson et al., 2015), China, Cuba, Mexico, Philippines, Singapore and Thailand (FAO, 2012) as a promising alternative for food security. For local commercialization, Brazilian sellers have cut the fish and obtained the ventral and dorsal parts. These cuts have been sold at the market for different prices, US\$ 3.75-5.00 per $\mathrm{kg}$ for ventral muscle and US\$ 6.25-7.00 per kg for dorsal muscle. Nevertheless, little is known about the flesh nutritional value of wild $A$. gigas, there is no scientific information regarding its fatty acid composition and whether there are differences between dorsal and ventral muscles.

Interest for studies regarding the nutritional and lipid value in foods has increased with particular focus on the highly unsaturated fatty acids (Hufa) of n-3 series, such as eicosapentaenoic (EPA; 20:5n-3) and docosahexaenoic (DHA; 22:6n-3) acids, due to their health benefits throughout human life (Inhamuns et al., 2009; Jabeen \& Chaudhry, 2011; Swanson et al., 2012). EPA and DHA are associated with important physiological functions, such as the proper fetal development including neuronal, retinal, and immune functions, as well as the prevention of cardiovascular problems and Alzheimer's disease (Swanson et al., 2012). Since these fatty acids are primarily obtained by diet, the World Health Organization recommends the minimum consumption of $200 \mathrm{mg}$ of EPA+DHA per day (WHO, 2015), and fish are considered to be one of the main natural sources of n-3 Hufa for human diets (Simopoulos, 2008; Inhamuns et al., 2009).

The objective of this work was to analyze the proximate and fatty acid composition of dorsal and ventral muscles of wild $A$. gigas, captured from a Brazilian Amazonian lake.

\section{Materials and Methods}

This study has been approved by the ethical committee of animal experimentation and research of the Instituto Nacional de Pesquisas da Amazônia (Inpa), municipality of Manaus, state of Amazonas, Brazil (Protocol number 002/2015).

Six wild fish $(48.80 \pm 14.34 \mathrm{~kg} ; 1.70 \pm 0.14 \mathrm{~m})$ were collected in the community of Ilha da Paciência $\left(3^{\circ} 22^{\prime} \mathrm{S}, 60^{\circ} 12^{\prime} \mathrm{W}\right)$, located in municipality of Iranduba, state of Amazonas, Brazil. Fish were captured using a dragnet and immediately slaughtered by medullary transection. Dorsal and ventral muscles were dissected out and kept in ice during the boat-land transportation to Inpa facilities, and were immediately stored in a freezer at $-80^{\circ} \mathrm{C}$. Afterwards, samples were freezedried, vacuum packed and sent to the chemistry department of the Universidade Estadual de Maringá for proximate and fatty acid composition analyses.

Moisture, ash and total protein in dorsal and ventral muscles were determined according to the procedures described by Horwitz (2005), and total lipids were determined by the Bligh \& Dyer (1959) method.

Fatty acid methyl esters were prepared by the method proposed by Santos Júnior et al. (2014). Methyl esters were separated by gas chromatography using a Thermo Scientific Trace Ultra Gas Chromatographer (Thermo Scientific, Waltham, MA, USA), fitted with a flame ionization detector (FID) and a fused-silica capillary column $(100 \mathrm{~m} \times 0.25 \mathrm{~mm}$ i.d., $0.25 \mu \mathrm{m}$ cyanopropyl CP-7420 select Fame). The operation parameters were as follows: detector temperature, $240^{\circ} \mathrm{C}$; injection port temperature, $230^{\circ} \mathrm{C}$; column temperature, $165^{\circ} \mathrm{C}$ for 18 minutes, programmed to increase at $4^{\circ} \mathrm{C} \mathrm{min}-1$ up to $235^{\circ} \mathrm{C}$, with final holding time of 14.5 minutes; carrier gas, hydrogen at $1.2 \mathrm{~mL} \mathrm{~min}^{-1}$; nitrogen was used as the makeup gas at $30 \mathrm{~mL} \mathrm{~min}^{-1}$; and there was split injection at $1 / 80$ ratio. For identification, the retention times of the fatty acids were compared 
to those of standard methyl esters (Sigma-Aldrich, St. Louis, MO, USA). Retention times and peak area percentages were automatically computed by a Software Chronquest 5.0. Quantification of fatty acids (mg g${ }^{-1}$ of total lipids) was performed using tricosanoic acid methyl ester (Sigma-Aldrich, USA) as an internal standard (23:0) (Joseph \& Ackman, 1992). Theoretical FID correction factor values were used to obtain concentration values of fatty acids in $\mathrm{mg} \mathrm{g}^{-1}$ of total lipids (Visentainer, 2012) by using the equation below: $\mathrm{FA}=[(\mathrm{AX} \times \mathrm{WIS} \times \mathrm{CFX}) /(\mathrm{AIS} \times \mathrm{CFAE} \times \mathrm{WX})]$; in which FA is fatty acid in $\mathrm{mg} \mathrm{g}^{-1}$ of total lipids, AX is the peak area (fatty acids), WIS is the weight (mg) of standard, CFX is the theoretical correction factor, AIS is the peak area standard (23:0), CFAE is the conversion factor necessary to express results as $\mathrm{mg}$ of fatty acid rather than as methyl ester, and WX is the sample weight $(\mathrm{g})$.

The nutritional quality of the lipid fraction of dorsal and ventral muscles of wild A. gigas was estimated by three indexes using the equations below: atherogenicity index (AI) (Ulbricht \& Southgate, 1991): $\mathrm{AI}=[12: 0+(4 \times 14: 0)+16: 0] / \sum \mathrm{Mufa}+\sum \mathrm{n}-6+\sum \mathrm{n}-3$, in which Mufa is monounsaturated FA; thrombogenicity index (TI) (Ulbricht \& Southgate, 1991): TI $=(14: 0+16: 0$ $+18: 0) /\left[0.5 \times\left(\sum \mathrm{Mufa}+\sum \mathrm{n}-6\right)\right]+\left(3 \times \sum \mathrm{n}-3\right)+\left(\sum \mathrm{n}-3 /\right.$ $\left.\sum \mathrm{n}-6\right)$; hypocholesterolemic and hypercholesterolemic fatty acid ratio $(\mathrm{H} / \mathrm{H})$ (Santos-Silva et al., 2002): $\mathrm{H} / \mathrm{H}=(18: 1 \mathrm{n}-9+18: 2 \mathrm{n}-6+18: 3 \mathrm{n}-3+20: 4 \mathrm{n}-6+20: 5 \mathrm{n}-3$ $+22: 5 n-3+22: 6 n-3) /(14: 0+16: 0)$.

For data analysis, proximate and fatty acid analyses of dorsal and ventral muscle were determined in triplicate for each fish. Proximate values were correlated between them by using Pearson's correlation at $5 \%$ probability. Means of proximate parameters, fatty acid composition and nutritional quality indexes of dorsal and ventral muscles were compared by student's t-test, at $5 \%$ probability. Data were processed using SigmaPlot 11.0 software.

\section{Results and Discussion}

The content of ash, total proteins and lipids was inversely proportional to moisture content and higher in ventral muscles of wild $A$. gigas (Table 1). Regarding the total lipid content found in both muscles, A. gigas is considered a medium fat fish $(4.00$ to $8.00 \%$ body fat) in accordance with the classification of Ackman
(1989). Moreover, this study reported higher lipid content in ventral muscles of wild A. gigas. In fact, it is known that ventral areas usually contain more lipids than the dorsal area in fishes (Thammapat et al., 2010).

Despite significant differences between the lipid contents, the fatty acid compositions in both muscles were quantitatively similar, except for heneicosylic (21:0), palmitoleic (16:1), $\gamma$-linolenic (18:3n-6) and dihomo- $\gamma$-linolenic (20:3n-6) acids (Table 2). In these sense, 27 fatty acids were quantified in both muscles, with predominance of saturated (SFA) and monounsaturated (Mufa) fatty acids, in a range from $295.32 \pm 27.55$ to $308.67 \pm 28.58$ (SFA), and from $242.24 \pm 28.49$ to $248.88 \pm 28.84$ (Mufa) ( $\mathrm{mg} \mathrm{g}^{-1}$ of total lipids) in dorsal and ventral muscles, respectively, without quantitative difference between them. Polyunsaturated fatty acids (Pufa) were lower than SFA and Mufa in the two analyzed muscles, varying from $158.22 \pm 11.93$ to $183.18 \pm 16.29$ ( $\mathrm{mg} \mathrm{g}^{-1}$ of total lipids) in dorsal and ventral muscles, respectively, being higher in the ventral part. A similar predominance pattern has been observed in some Amazonian fish, such as the tucunaré (Cichla sp.) in dry season (Inhamuns et al., 2009); mapará (Hypophthalmus sp.) (Inhamuns \& Franco, 2001); and spotted sorubim (Pseudoplatystoma corruscans) (Tanamati et al., 2009); as well as in wild freshwater fish from other regions (Jabeen \& Chaudhry, 2011).

The predominant fatty acids in both dorsal and ventral muscles were palmitic $(16: 0 ; 180.03 \pm 34.05$ to $185.38 \pm 15.21$ $\mathrm{mg} \mathrm{g}^{-1}$ of total lipids), oleic (18:1n-9; $139.00 \pm 37.02$ to $158.69 \pm 29.56 \mathrm{mg} \mathrm{g}^{-1}$ of total lipids), linoleic (18:2n-6; $78.44 \pm 11.82$ to $86.02 \pm 14.51 \mathrm{mg} \mathrm{g}^{-1}$ of total lipids) and stearic $\left(18: 0 ; 73.72 \pm 14.02\right.$ to $87.94 \pm 11.63 \mathrm{mg} \mathrm{g}^{-1}$ of total lipids) acids. These fatty acids have mainly been found in other freshwater species, with higher predominance of

Table 1. Proximate composition ( $\%$ in wet weight basis) of dorsal and ventral muscle of wild Arapaima gigas from Brazilian Amazon ${ }^{(1)}$.

\begin{tabular}{lcc}
\hline Composition & Dorsal muscle & Ventral muscle \\
\hline Moisture & $79.52 \pm 0.64 \mathrm{a}$ & $76.07 \pm 1.57 \mathrm{~b}$ \\
Ash & $0.59 \pm 0.04 \mathrm{a}$ & $0.74 \pm 0.08 \mathrm{~b}$ \\
Total proteins & $13.09 \pm 0.56 \mathrm{a}$ & $14.50 \pm 1.33 \mathrm{~b}$ \\
Total lipids & $6.38 \pm 0.45 \mathrm{a}$ & $8.26 \pm 0.49 \mathrm{~b}$ \\
\hline
\end{tabular}

(1)Means followed by equal letters within rows, do not differ, by Student's t-test, at $5 \%$ probability. Results are shown as means \pm standard deviations of triplicate analyses per fish $(n=6)$.

Pesq. agropec. bras., Brasília, v.52, n.4, p.271-276, abr. 2017 DOI: $10.1590 / \mathrm{S} 0100-204 X 2017000400007$ 
palmitic and oleic acids (Table 2), as observed in mapará, C. carpio, L. rohita, and O. mossambicus (Jabeen \& Chaudhry, 2011).

All the quantified Pufa showed quite similar values in both dorsal and ventral muscles of wild A. gigas, except for linoleic acid, which was higher than the other Pufa and is considered one of the essential fatty acids for freshwater fish (NRC, 2011). Probably, the highest proportion of linoleic acid in

Table 2. Fatty acid composition ( $\mathrm{mg} \mathrm{g}^{-1}$ of total lipids) of dorsal and ventral muscle of wild Arapaima gigas from Brazilian Amazon ${ }^{(1)}$.

\begin{tabular}{|c|c|c|}
\hline Fatty acid/acid & Dorsal muscle & Ventral muscle \\
\hline 12:0/lauric & $1.27 \pm 0.43$ & $1.86 \pm 0.95$ \\
\hline 13:0/tridecanoic & $1.16 \pm 0.66$ & $1.41 \pm 0.58$ \\
\hline 14:0/myristic & $12.10 \pm 1.75$ & $11.27 \pm 2.24$ \\
\hline 15:0/pentadecanoic & $2.85 \pm 1.08$ & $2.77 \pm 1.03$ \\
\hline 16:0/palmitic & $185.38 \pm 15.21$ & $180.03 \pm 34.05$ \\
\hline 17:0/margaric & $2.08 \pm 0.88$ & $2.05 \pm 0.74$ \\
\hline 18:0/stearic & $73.72 \pm 14.02$ & $87.94 \pm 11.63$ \\
\hline 20:0/arachidic & $1.42 \pm 0.40$ & $1.05 \pm 0.37$ \\
\hline 21:0/heneicosanoic & $2.11 \pm 0.18 \mathrm{a}$ & $0.89 \pm 0.08 b$ \\
\hline 22:0/behenic & $7.20 \pm 3.05$ & $10.19 \pm 3.34$ \\
\hline 24:0/lignoceric & $6.04 \pm 3.20$ & $9.21 \pm 3.07$ \\
\hline$\sum$ SFA & $295.32 \pm 27.55$ & $308.67 \pm 28.58$ \\
\hline 14:1/myristoleic & $4.21 \pm 1.26$ & $4.36 \pm 1.29$ \\
\hline 15:1/pentadecenoic & $2.90 \pm 0.47$ & $2.49 \pm 0.70$ \\
\hline 16:1/palmitoleic & $54.47 \pm 14.99 \mathrm{a}$ & $78.44 \pm 21.27 b$ \\
\hline 17:1/heptadecenoic & $2.31 \pm 0.59$ & $2.49 \pm 1.21$ \\
\hline 18:1n-9/oleic & $158.69 \pm 29.56$ & $139.00 \pm 37.02$ \\
\hline 20:1n-9/eicosenoic & $10.88 \pm 4.37$ & $9.86 \pm 1.73$ \\
\hline 24:1n-9/nervonic & $8.79 \pm 4.50$ & $12.24 \pm 2.63$ \\
\hline$\sum$ Mufa & $242.24 \pm 28.49$ & $248.88 \pm 28.84$ \\
\hline 18:2n-6/linoleic & $78.44 \pm 11.82$ & $86.02 \pm 14.51$ \\
\hline 18:3n-6/gamma-linolenic & $9.62 \pm 3.65 \mathrm{a}$ & $16.06 \pm 2.52 \mathrm{~b}$ \\
\hline 18:3n-3/alpha-linolenic & $8.12 \pm 1.91$ & $11.12 \pm 2.74$ \\
\hline 20:2n-6/eicosadienoic & $8.08 \pm 1.88$ & $9.66 \pm 1.79$ \\
\hline 20:3n-6/eicosatrienoic & $12.99 \pm 4.55 \mathrm{a}$ & $7.49 \pm 2.90 \mathrm{~b}$ \\
\hline 20:4n-6/arachidonic & $14.67 \pm 3.20$ & $20.91 \pm 6.81$ \\
\hline 20:5n-3/eicosapentaenoic & $9.25 \pm 4.73$ & $10.14 \pm 2.90$ \\
\hline $22: 4 n-6 /$ docosatetraenoic & $8.54 \pm 4.03$ & $11.17 \pm 5.19$ \\
\hline 22:6n-3/docosahexaenoic & $8.50 \pm 1.25$ & $10.63 \pm 2.56$ \\
\hline$\sum$ Pufa & $158.22 \pm 11.93 \mathrm{a}$ & $183.18 \pm 16.29 \mathrm{~b}$ \\
\hline$\overline{\sum n-6}$ & $132.35 \pm 13.08 \mathrm{a}$ & $151.30 \pm 16.12 b$ \\
\hline$\sum \mathrm{n}-3$ & $25.87 \pm 6.15$ & $31.89 \pm 5.84$ \\
\hline EPA+DHA & $17.75 \pm 4.91$ & $20.77 \pm 5.37$ \\
\hline$\sum$ Fatty acids & $695.79 \pm 47.15$ & $740.73 \pm 31.75$ \\
\hline
\end{tabular}

${ }^{(1)}$ Means followed by equal letters within rows, do not differ, by Student's t-test, at $5 \%$ probability. SFA, saturated fatty acids; Mufa, monounsaturated fatty acids; Pufa, polyunsaturated fatty acids; EPA, eicosapentaenoic acid; and DHA, docosahexaenoic acid. Results are shown as means \pm standard deviations of triplicate analyses per fish $(n=6)$. both muscles comes from the fish diet, since $A$. gigas is a carnivorous fish showing a preference for fishes of the Loricariidae family, which are mainly herbivorous and planctophagic (Fontenele, 1948). Actually, the fatty acid composition is strongly influenced by the age, feeding, reproductive cycle, season, salinity, geographical location and biology of the fish species. Therefore, different results can be found even in the same species under different conditions (Inhamuns et al., 2009; Jabeen \& Chaudhry, 2011).

The amounts of EPA and DHA were similar between dorsal and ventral muscles - 9.25 \pm 4.73 (dorsal) to $10.14 \pm 2.90$ (ventral); $8.50 \pm 1.25$ (dorsal) to $10.63 \pm 2.56$ (ventral) $\mathrm{mg} \mathrm{g}^{-1}$ of total lipids, respectively. The n-6 fatty acids showed higher proportions than the $\mathrm{n}-3$ fatty acids in both dorsal and ventral muscles, especially linoleic and arachidonic - 20:4n-6; $14.67 \pm 3.20$ (dorsal) to $20.91 \pm 6.81$ (ventral) $\mathrm{mg} \mathrm{g}^{-1}$ of total lipids - acids (Table 2). The proportion of EPA in both dorsal and ventral muscles of wild A. gigas (Table 2) was higher in comparison with other Amazonian fishes, such as the matrinxã (Brycon cephalus) (5.20-8.10 $\mathrm{mg} \mathrm{g}^{-1}$ of total lipids), tambaqui (Colossoma macropomum) $\left(4.70 \mathrm{mg} \mathrm{g}^{-1}\right.$ of total lipids) and Cichla sp. (6.00-9.00 $\mathrm{mg} \mathrm{g}^{-1}$ of total lipids) (Almeida et al., 2008, 2009; Inhamuns et al., 2009), although the DHA in A. gigas was lower when compared to the above mentioned fish.

The sum of EPA and DHA in A. gigas reached $113.25 \mathrm{mg}$ and $165.78 \mathrm{mg}$ in $100 \mathrm{~g}$ of dorsal and ventral muscles, respectively. It means that a person should eat at least $120.64 \mathrm{~g}$ of ventral muscle or $176.60 \mathrm{~g}$ of dorsal muscle to achieve the minimum EPA+DHA amount of $200 \mathrm{mg}$ per day as recommended by the World Health Organization (WHO, 2015). That amount of flesh is relatively small in comparison to the size that $A$. gigas could reach and considering its availability in the Amazonian market.

The Pufa/SFA, n-3/n- 6 and $\mathrm{H} / \mathrm{H}$ ratios, as well as the AI and TI indexes, indicate that wild $A$. gigas flesh could be beneficial for human health. The Pufa/SFA ratio in A. gigas (Table 3) is higher than the value (0.45) recommended by the Department of Health and Social Security of the United Kingdom (DHSS, 1984), which considers diets with a Pufa/SFA ratio below 0.45 as not healthy due to their potential in inducing cholesterol increase in the blood. 
The $\mathrm{n}-6$ series fatty acids showed higher proportions than the $n-3$ in both dorsal and ventral muscles, especially linoleic and arachidonic acids - 20:4n-6; $14.67 \pm 3.20$ (arachidonic, dorsal) to $20.91 \pm 6.81$ (arachidonic, ventral) $\mathrm{mg} \mathrm{g}^{-1}$ of total lipids. The n-3/n-6 ratios in $A$. gigas were not quantitatively different between muscles. However, these data are lower when compared with the ones of other Amazonian fish, such as the Cichla sp. (0.66-0.98) (Inhamuns et al., 2009), C. macropomum (0.41) (Almeida et al., 2008) and Hypophthalmus sp. (1.5-1.6) (Inhamuns \& Franco, 2001). In those fish, all the $n-3 / n-6$ ratios were affected by the high proportion of DHA in their muscles. Nevertheless, nutritionists believe that the n-3/n-6 ratio should be at least 0.20 (Simopoulos, 2008) to provide nutraceutical benefits for human health, and the $A$. gigas ratio was into that limit.

The hypocholesterolemic and hypercholesterolemic fatty acid ratio $(\mathrm{H} / \mathrm{H})$ considers the specific effects of fatty acids on cholesterol metabolism, and higher $\mathrm{H} / \mathrm{H}$ values are considered beneficial for human health. The obtained $\mathrm{H} / \mathrm{H}$ values of $1.41 \pm 0.20$ and $1.45 \pm 0.42$ for dorsal and ventral muscles, respectively are higher than those found in other commercially important freshwater fish (Table 3), such as the flatwhiskered catfish (Pinirampus pirinampu) (1.14) (Ramos-Filho et al., 2010), Hypophthalmus sp. (0.75) (Inhamuns \& Franco, 2001), pirapitinga (Piaractus brachypomus) (1.29) and sorubim Pseudoplatystoma fasciatum (0.52) (Perea et al., 2008).

The atherogenicity (AI) and thrombogenicity (TI) indexes indicate the potential to stimulate platelet aggregation. Thus, lower AI and TI values have

Table 3. Nutritional quality indexes of the lipid fraction of dorsal and ventral muscle of wild Arapaima gigas from Brazilian Amazon ${ }^{(1)}$.

\begin{tabular}{lcc}
\hline Lipid fraction & Dorsal muscle & Ventral muscle \\
\hline Pufa/SFA & $0.54 \pm 0.07 \mathrm{a}$ & $0.59 \pm 0.11 \mathrm{a}$ \\
n-3/n-6 & $0.20 \pm 0.06 \mathrm{a}$ & $0.21 \pm 0.05 \mathrm{a}$ \\
H/H & $1.41 \pm 0.20 \mathrm{a}$ & $1.45 \pm 0.42 \mathrm{a}$ \\
Atherogenicity index (AI) & $0.59 \pm 0.08 \mathrm{a}$ & $0.53 \pm 0.09 \mathrm{a}$ \\
Thrombogenicity index (TI) & $1.02 \pm 0.16 \mathrm{a}$ & $0.94 \pm 0.14 \mathrm{a}$ \\
\hline
\end{tabular}

${ }^{(1)}$ Means followed by equal letters within rows do not differ, by Student's t-test, at $5 \%$ probability. Pufa/SFA, total polyunsaturated fatty acids/total saturated fatty acids ratio; $n-3 / n-6$, total $n-3$ fatty acids/total $n-6$ fatty acids ratio; $\mathrm{H} / \mathrm{H}$, hypocholesterolemic and hypercholesterolemic fatty acid ratio. Results are shown as means \pm standard deviations of triplicate analyses per fish $(n=6)$. beneficial effects in preventing coronary artery diseases (Ulbricht \& Southgate, 1991). Both dorsal and ventral muscles showed lower AI $(0.59 \pm 0.08$ and $0.53 \pm 0.09)$ and TI $(1.02 \pm 0.16$ and $0.94 \pm 0.14)$ values (Table 3) when comparing to other freshwater fish, such as the $P$. pirinampu $(\mathrm{AI}=0.79$; $\mathrm{TI}=1.18)$, jaú (Paulicea luetkeni) $(\mathrm{AI}=0.62 ; \mathrm{TI}=1.00)($ RamosFilho et al., 2010), and $P$. brachypomus (AI $=1.10$; $\mathrm{TI}=1.49$ ) (Perea et al., 2008), indicating that $\mathrm{A}$. gigas flesh could be beneficial for human health.

\section{Conclusions}

1. Dorsal and ventral muscles of wild Pirarucu are a good dietary source of eicosapentaenoic and docosahexaenoic acids (EPA+DHA), highly unsaturated fatty acids.

2. Both dorsal and ventral muscles show lower atherogenicity and thrombogenicity indexes, which indicate beneficial effects in preventing coronary artery diseases.

3. The lipids nutritional quality of Pirarucu flesh can be beneficial for human health.

\section{Acknowledgements}

To Financiadora de Estudos e Projetos (Finep), for the logistic and financial support in fish catch (Darpa 01.09.0472.00).

\section{References}

ACKMAN, R.G. Nutritional composition of fats in seafoods. Progress in Food and Nutrition Science, v.13, p.161-289, 1989.

ALMEIDA, N.M.; JANZANTTI, N.S.; FRANCO, M.R.B. Determination of essential fatty acids in captured and farmed matrinxã (Brycon cephalus) from the Brazilian Amazonian Area. Journal of the American Oil Chemists Society, v.86, p.717-722, 2009. DOI: 10.1007/s11746-009-1416-1.

ALMEIDA, N.M.; VISENTAINER, J.V.; FRANCO, M.R.B. Composition of total, neutral and phospholipids in wild and farmed tambaqui (Colossoma macropomum) in the Brazilian Amazon area. Journal of the Science of Food and Agriculture, v.88, p.1739-1747, 2008. DOI: 10.1002/jsfa.3274.

BLIGH, E.G.; DYER, W.J. A rapid method of total lipid extraction and purification. Canadian Journal of Biochemistry and Physiology, v.37, p.911-917, 1959. DOI: 10.1139/o59-099.

CAVOLE, L.M.; ARANTES, C.C.; CASTELlO, L. How illegal are tropical small-scale fisheries? An estimate for arapaima in the Amazon. Fisheries Research, v.168, p.1-5, 2015. DOI: 10.1016/j. fishres.2015.03.012. 
CITES. Convention on International Trade in Endangered Species of Wild Fauna and Flora. Appendices I, II and II: valid from 5 February 2015. 2015. Available at: <https://www.cites.org/ sites/default/files/eng/app/2015/E-Appendices-2015-02-05.pdf $>$. Accessed on: Apr. 42016.

DHSS. Department of Health and Social Security. Diet and cardiovascular disease. London: Department of Health and Social Security, 1984. (Report on Health and Social Subjects, 28).

FAO. Food and Agriculture Organization of the United Nations. Cultured Aquatic Species Information Programme: Arapaima gigas (Schinz, 1822). 2012. Available at: $<$ http://www.fao.org/ fishery/culturedspecies/Arapaima_gigas/en>. Accessed on: Apr. 152016.

FONTENELE, O. Contribuição para o conhecimento da biologia do pirarucu Arapaima gigas (Cuvier) em cativeiro (Actinopterygi, Osteoglossidae). Revista Brasileira de Biologia, v.8, p.445-449, 1948.

HILL, J.E.; LAWSON, K.M. Risk screening of Arapaima, a new species proposed for aquaculture in Florida. North American Journal of Fisheries Management, v.35, p.885-894, 2015. DOI: 10.1080/02755947.2015.1064835.

HORWITZ, W. (Ed.). Official Methods of Analysis of the AOAC International. $18^{\text {th }}$ ed. Gaithersburg: Association of Official Analytical Chemists, 2005. 771p.

INHAMUNS, A.J.; FRANCO, M.R.B. Composition of total, neutral, and phospholipids in mapará (Hypophthalmus sp.) from the Brazilian Amazonian area. Journal of Agricultural and Food Chemistry, v.49, p.4859-4863, 2001. DOI: 10.1021/jf0100393.

INHAMUNS, A.J.; FRANCO; M.R.B.; BATISTA, W.S. Seasonal variations in total fatty acid composition of muscles and eye sockets of tucunaré (Cichla sp.) from the Brazilian Amazon area. Food Chemistry, v.117, p.272-275, 2009. DOI: 10.1016/j. foodchem.2009.03.113.

JABEEN, F.; CHAUDHRY, A.S. Chemical compositions and fatty acid profiles of three freshwater fish species. Food Chemistry, v.125, p.991-996, 2011. DOI: 10.1016/j.foodchem.2010.09.103.

JOSEPH, J.D.; ACKMAN, R.G. Capillary column gas chromatographic method for analysis of encapsulated fish oils and fish oil ethyl esters: collaborative study. Journal of AOAC International, v.75, p.488-506, 1992.

LAWSON, L.L.; TUCKETT, Q.M.; LAWSON, K.M.; WATSON, C.A.; HILL, J.E. Lower lethal temperature for Arapaima Arapaima gigas: potential implications for cultures and establishment in Florida. North American Journal of Aquaculture, v.77, p.497502, 2015. DOI: 10.1080/15222055.2015.1066471.

NRC. National Research Council. Nutrient requirements of fish and shrimp. Washington: National Academies Press, 2011. 376p.

NÚÑEZ, J.; CHU-KOO, F.; BERLAND, M.; ARÉVALO, L.; RIBEYRO, O.; DUPONCHELLE, F.; RENNO, J.F. Reproductive success and fry production of the paiche or pirarucu, Arapaima gigas (Schinz), in the region of Iquitos, Perú. Aquaculture Research, v.42, p.815-822, 2011. DOI: 10.1111/j.13652109.2011.02886.x.

PEREA, A.; GÓMEZ, E.; MAYORGA, Y.; TRIANA, C.Y. Caracterización nutricional de pescados de produccion $\mathrm{y}$ consumo regional en Bucaramanga, Colombia. Archivos Latinoamericanos de Nutrición, v.58, p.91-97, 2008.

RAMOS-FILHO, M.M.; RAMOS, M.I.L.; HIANE, P.A.; SOUZA, E.M.T. de. Nutritional value of seven freshwater fish species from the Brazilian Pantanal. Journal of the American Oil Chemists' Society, v.87, p.1461-1467, 2010. DOI: 10.1007/s11746-010-1639-1.

SANTOS JÚNIOR, O.O.; MONTANHER, P.F.; BONAFÉ, E.G.; PRADO, I.N. do; MARUYAMA, S.A.; MATSUSHITA, M.; VISENTAINER, J.V. A simple, fast and efficient method for transesterification of fatty acids in foods assisted by ultrasound energy. Journal of the Brazilian Chemical Society, v.25, p.17121719, 2014. DOI: 10.5935/0103-5053.20140166.

SANTOS-SILVA, J.; BESSA, R.J.B.; SANTOS-SILVA, F. Effect of genotype, feeding system and slaughter weight on the quality of light lambs. II. Fatty acid composition of meat. Livestock Production Science, v.77, p.187-194, 2002. DOI: 10.1016/S03016226(02)00059-3.

SIMOPOULOS, A.P. The importance of the omega-6/omega-3 fatty acid ratio in cardiovascular disease and other chronic diseases. Experimental Biology and Medicine, v.233, p.674688, 2008. DOI: 10.3181/0711-MR-311.

SWANSON, D.; BLOCK, R.; MOUSA, S.A. Omega-3 fatty acids EPA and DHA: health benefits throughout life. Advances in Nutrition, v.3, p.1-7, 2012. DOI: 10.3945/an.111.000893.

TANAMATI, A.; STEVANATO, F.B.; VISENTAINER, J.E.L.; MATSUSHITA, M.; SOUZA, N.E. de; VISENTAINER, J.V. Fatty acid composition in wild and cultivated pacu and pintado fish. European Journal of Lipid Science and Technology, v.111, p.183-187, 2009. DOI: 10.1002/ejlt.200800103.

THAMMAPAT, P.; RAVIYAN, P.; SIRIAMORNPUN, S. Proximate and fatty acids composition of the muscles viscera of Asian catfish (Pangasius bocourti). Food Chemistry, v.122, p.223-227, 2010. DOI: 10.1016/j.foodchem.2010.02.065.

ULBRICHT, T.L.V.; SOUTHGATE, D.A.T. Coronary heart disease: seven dietary factors. The Lancet, v.338, p.985-992, 1991. DOI: 10.1016/0140-6736(91)91846-M.

VISENTAINER, J.V. Aspectos analíticos da resposta do detector de ionização em chama para ésteres de ácidos graxos em biodiesel e alimentos. Química Nova, v.35, p.274-279, 2012. DOI: 10.1590/ S0100-40422012000200008.

WHO. World Health Organization. Nutrition: population nutrient intake goals for preventing diet-related chronic diseases. 2015. Available at: <http://www.who.int/nutrition/ topics/5_population_nutrient/en/index13.html $>$. Accessed on: May 122016.

Received on October 10, 2016 and accepted on February 13, 2017

Pesq. agropec. bras., Brasília, v.52, n.4, p.271-276, abr. 2017

DOI: 10.1590/S0100-204X2017000400007 